\title{
Introduction of antifungal genes in sunflower via Agrobacterium
}

\author{
Laura Mabel Radonic \\ Instituto de Biotecnología \\ INTA Castelar \\ De los Reseros y Nicolás Repetto s/n (1712), Castelar \\ Buenos Aires, Argentina \\ Tel: $541146211278 / 1447$ \\ Fax: 541146210199 \\ E-mail: 1radonic@cnia.inta.gov.ar \\ Julián Marcos Zimmermann" \\ Instituto de Biotecnología \\ INTA Castelar \\ De los Reseros y Nicolás Repetto s/n (1712), Castelar \\ Buenos Aires, Argentina \\ Tel: 543878494492 \\ Fax: 543878493190 \\ E-mail: jzimmerman@cnia.inta.gov.ar \\ Diego Zavallo \\ Instituto de Biotecnología \\ INTA Castelar \\ De los Reseros y Nicolás Repetto s/n (1712), Castelar \\ Buenos Aires, Argentina \\ Tel: 54114621 1278/1447 \\ Fax: 541146210199 \\ E-mail: dzavallo@cnia.inta.gov.ar \\ Nilda López \\ Instituto de Biotecnología \\ INTA Castelar \\ De los Reseros y Nicolás Repetto s/n (1712), Castelar \\ Buenos Aires, Argentina \\ Tel: 54114621 1278/1447 \\ Fax: 541146210199 \\ E-mail: nelopez@cnia.inta.gov.ar

\section{Marisa López Bilbao*} \\ Instituto de Biotecnología

$$
\text { INTA Castelar }
$$ \\ De los Reseros y Nicolás Repetto s/n (1712), Castelar \\ Buenos Aires, Argentina \\ Tel: 54114621 1278/1447 \\ Fax: 541146210199 \\ E-mail: mlopezbilbao@cnia.inta.gov.ar
}

Financial support: National Agency of Scientific and Technological Promotion (ANPCyT), PICTO Nº 08-13164 and 08-12925, Argentina.

Keywords: antifungal genes, double expression cassettes, polyprotein cassettes, sunflower, transgenic plants.

"Present address: Chacra Experimental Agrícola, PO box $\mathrm{n}^{\circ} 8$ (A4531WAA), Colonia Santa Rosa, Salta, Argentina. E-mail: jzimmermann@chacraexperimental.org.

Abbreviations: CTAB: Cetyltrimethylammonium bromide

DNA: deoxyribonucleic acid

Km: kanamycin

PCR: polymerase chain reaction

Rip: ribosome inhibitor protein

TEV: tobacco etch virus

TMV: tobacco mosaic virus

*Corresponding author 
There is evidence that overexpression of transgenes codifying antifungal proteins may confer protection to pathogen attack, and that this protection is increased due to the synergic effect of the expression of two or more genes. On the other hand it is well known that sunflower is a recalcitrant specie, highly difficult to be genetically transformed. In this context, the final aim of this project was to obtain sunflower plants expressing at least two antifungal genes, avoiding sequential transformation. The antifungal genes used encode for two enzymes that degrade the fungal wall (glucanase and chitinase), an osmotin and a ribosome inhibitor protein. Two types of transformation vectors were used: a more traditional system with a double cassette and a novel system producing a unique polyprotein with antifungal proteins released in equimolecular quantities. The polyprotein vector system generated hyperhydric shoots with necrotic areas and abnormal growth at the end of the tissue culture procedure, making impossible the use of this interesting vector in sunflower. Transformation assays carried out with the pHGC39 vector (including glucanase and chitinase genes) vector produced $0.83 \%$ efficiency, corresponding to 13 rooted shoots in kanamycin $(\mathrm{Km})$ from a total of 1568 agroinfected shoots. T0 rooted shoots resulted positive by PCR analysis and were transferred to greenhouse to obtain their offspring. In addition, we corroborate the transformation protocol using $\mathrm{Km}$ as selective marker, previously described (Radonic et al. 2006) with a reporter gene, but in this opportunity with antifungal genes.

Significant limitations to sunflower (Helianthus sp.) culture are fungal diseases, like those caused by Verticillium dahliae and Sclerotinia sclerotiorum, because they not only affect yield but also affect the quality of the products. Conventional genetic improvement has not been efficient to confer resistance, caused by the limited sources of effective natural resistance to main pathogens and also to the polygenic character of the resistance to pathogens like Sclerotinia.

There is evidence that the overexpression of transgenes codifying antifungal proteins may confer protection to pathogen attack, and this protection is increased due to the synergic effect of the expression of two or more genes (Punja, 2001). The expression of genes encoding enzymes capable of degrading the major constituents of fungal cell walls (chitin and $\beta-1.3$-glucan) have been used as a strategy, for example in tomato, that showed a useful level of resistance to a Fusarium wilt disease and in tobacco where the presence of two genes increases the resistance to Rhizoctonia solani both examples reviewed in Melchers and Stuiver (2000).

Despite several publications in sunflower genetic transformation (Hewezi et al. 2002; Weber et al. 2003), there was no efficient or reproducible protocol. In a previous publication (Radonic et al. 2006) we determined that the selection by in vitro rooting in a $\mathrm{Km}$ culture medium is a successful method as no escapes were obtained. Nevertheless some difficulties remain in sunflower transformation as the in vitro regeneration of plantlets (T0) is via organogenesis, producing chimeras that not necessarily will give an offspring (T1) that carries and/or express the transgene. Therefore, the application of sequential transformation steps to introduce several genes in sunflower is extremely difficult.

In this context, the final aim of this project is to obtain sunflower plants expressing at least two antifungal genes. For the incorporation of these genes, we used two types of transformation vectors, a traditional system with a double cassette and a novel system based on the ability of the NIa protease from the Tobacco Etch Virus (TEV) for autocleavage and to recognize specific cleavage sequences which produce an unique polyprotein producing equimolecular antifungal protein quantities. The antifungal

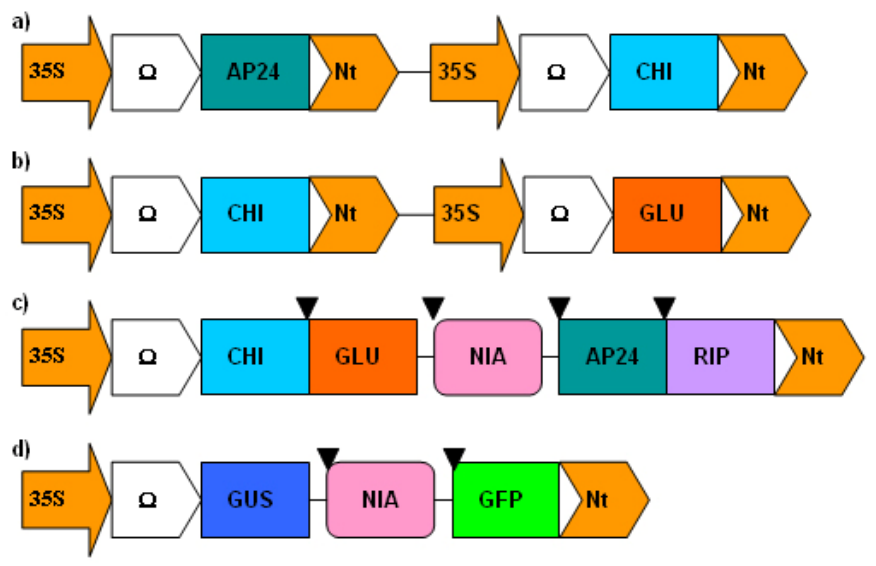

Figure 1. Constructions used for the transformation with antifungal genes. a) and b) Double expression cassettes containing AP24 and chitinase $(\mathrm{CHI})$ genes or $\mathrm{CHI}$ and glucanase (GLU) genes respectively. c) Polyprotein construction containing genes of interest (CHI, GLU, NIA protease, AP24, and the Ribosome Inhibitor Protein (RIP). d) Polyprotein construction containing GUS and GFP reporter genes and NIA protease gene. 

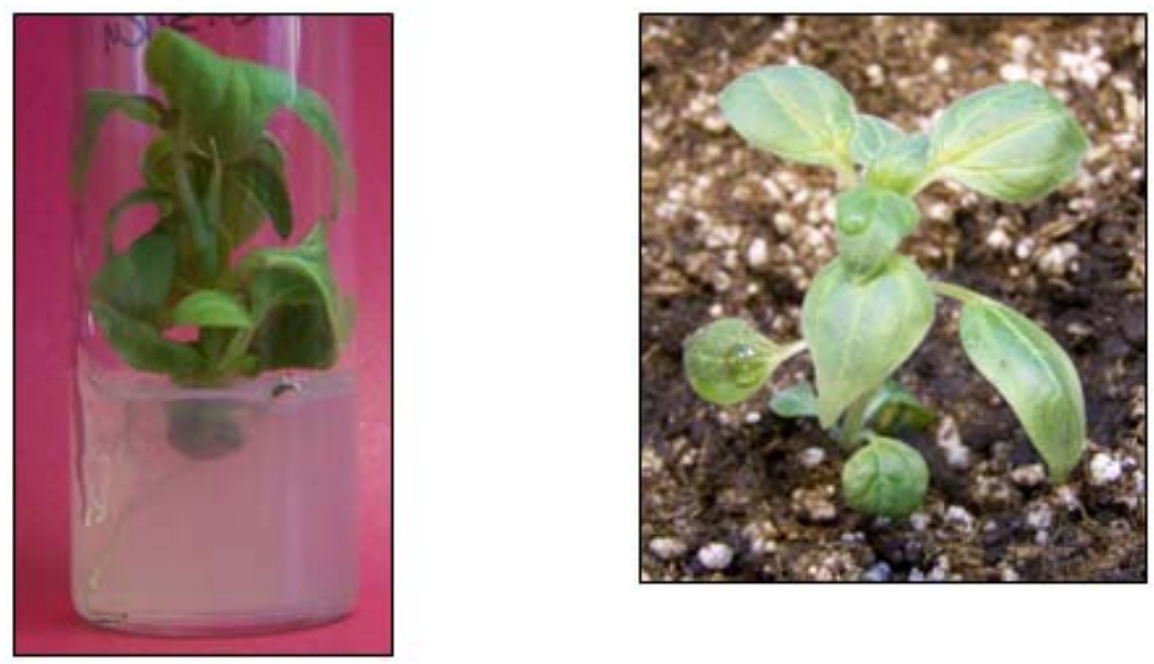

Figure 2. Transgenic shoots with the construction containing chitinase and glucanase genes (Figure 1b).

genes used codify for two enzymes that degrade the fungal wall (glucanase and chitinase), an osmotin and a ribosome inhibitor protein.

\section{MATERIALS AND METHODS}

Seeds from the public genotype HA89 were used as plant material. Agrobacterium tumefaciens EHA105 and 101 strains (Hood et al. 1993) were used. Transformation and tissue culture were performed as described previously in Radonic et al. (2006) with slight modifications in the selection method: $1 \mathrm{mg} / \mathrm{l}$ and $10 \mathrm{mg} / \mathrm{l} \mathrm{kanamycin} \mathrm{were}$ added in the first and second regeneration media, respectively.

The antifungal genes used were gln2 (glucanase) from $N$. tabacum, ch5B (chitinase) from $P$. vulgaris, ap24 (osmotin) from $N$. tabacum and rip (ribosome inhibitor protein). These genes were incorporated using two different types of vector:

1) Double expression cassette vectors: These vectors were kindly provided by L. Hernández (CIGB; Cuba) where genes are in pairs, each one with the CaMV35S promoter, the $\mathrm{W}$ enhancer from TMV and the nopaline sintase $(\mathrm{Nt})$ terminator. These vectors are pHCA35, containing ch5B and ap24 genes (Figure 1a) and pHGC39, containing ch5B and gln2 genes (Figure 1b).

2) Polyprotein vector: This vector is based on the ability of the NIa protease from the Tobacco Etch Virus (TEV) for autocleavage and to recognize specific cleavage sequences. This vector contains the four antifungal genes which translate as a single polyprotein under the regulation of a single CaMV35S promoter and the $\mathrm{W}$ enhancer from Tobacco Mosaic Virus (TMV) and the $N t$ terminator. Each gene is preceded by the cleavage recognition sequence for the protease action (Figure 1c). As a control and model of this system a vector containing gus and $g f p$ reporter genes was used (Figure 1d).

In addition, all these vectors contain the nptII (neomycin phosphotransferase) gene regulated by nos (nopaline sintase) promoter and oct (octopine sintase) terminator.

Genomic DNA extraction was performed using the CTAB method (Saghai-Maroof et al. 1984). PCR was performed for a fragment of ch5B gene using Invitrogen Taq polimerase (1 U), Promega Green Go Taq Buffer (1X) and $0.1 \mu \mathrm{M}$ of each primer (35S f: 5'CGCACAATCCCACTATCCTT-3' and chi r: 5'GAGGGCGCTGAGATCAGTAG-3'). Negative controls: mix without the addition of DNA and another with DNA from a non-transformed plant. Positive control: pHGC39 plasmid DNA.

\section{RESULTS AND DISCUSSION}

Both polyprotein vectors, containing antifungal or reporter genes, were used to transform a total of 1524 shoots. All these shoots presented hyperhydric aspect, with necrotic areas and abnormal growth at the end of the culture procedure. Besides, and probably associated to this in vitro behavior, no shoots rooted in the selective media containing kanamicyn. The in vitro response described here was never observed in our lab previously. It must be mentioned that materials (media, seeds, Agrobacteria strains), conditions (growing chambers, laminar flows, vacuum bombs, etc.) and researchers and technicians were the same in all the assays done by our group, both with antifungal vectors described in this work as with other vectors carrying reporter genes or different selective genes. Therefore this hyperhydric aspect and abnormal in vitro growth could be related to the presence of the NIa gene. Virus diseases of cultivated sunflower (Helianthus annuus L.) or other wild species of the genus Helianthus are rare, and nine of the 


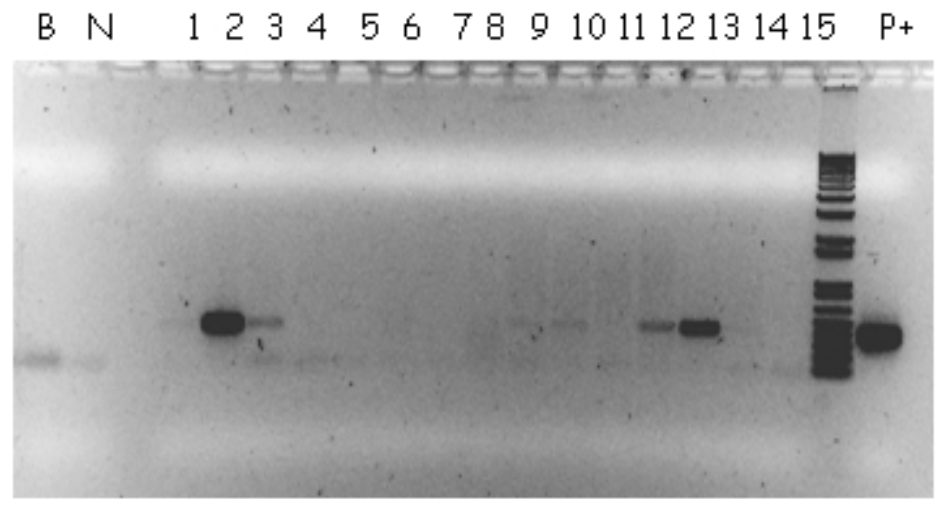

Figure 3. PCR performed for a fragment of chitinase gene. 1, 2, 3, 8, 9, 10, 11, 12 and 13: DNA from in vitro rooted shoots. 4, 5, 6, 7, 14 and 15: DNA from non-rooted shoots chosen randomly.

$\mathrm{B}$ : mix without the addition of DNA, N: DNA from non-transformed sunflower, $\mathrm{P}+$ : positive control pHGC39 plasmid DNA.

viruses reported to infect sunflower naturally or experimentally, belong to the family Potyviridae (Gulya et al. 2002). The NIa protease gene used in these constructions is from the TEV the Potyviridae most closely related to the Sunflower Mosaic Virus (SuMV) (Gulya et al. 2002). For that reason, sunflower tissues could be detecting the presence of this protease activity not only in stable transformed shoots but also in those shoots with a transient transformation expression. This tissue culture response described here resulted in the impossibility of using this interesting vector system in sunflower.

The double expression cassette vectors used in this work were successfully used in strawberry (Vellicce et al. 2006). When these double expression cassette vectors were used for sunflower transformation, we observed different results at the in vitro response level. In the case of the pHGC39 vector, the transformation efficiency obtained was $0.83 \%$, corresponding to 13 rooted shoots in $\mathrm{Km}$ of a total of 1568 agroinfected shoots (Figure 2a). PCR analysis from rooted shoots (T0), using primers $35 S f$ and chi $r$, produced the expected amplified fragment from the $35 \mathrm{~S}$ promoter to the chitinase gene sequence (Figure 3). All these rooted shoots were transferred to greenhouse to obtain their offspring (Figure 2b). T1 and T2 are being molecularly characterized and they will allow us to analyze the response to pathogens.

In those transformation assays where pHCA35 double expression vector was used no rooted shoots were obtained of a total of 452 treated shoots. This high dependence of the transformation efficiency on the DNA sequence used is a known effect in other species transformation.

This work corroborates the efficiency of the transformation/selection method in presence of kanamycin where no escapes were obtained, since all shoots that were able to root in vitro in presence of the antibiotic carried the transgene.
It must be mentioned that in our laboratory we have found some examples of transgenic instability as some T1 plants which expressed the transgen then lost it at the following generation. This situation was described by McCabe et al. (1999) in lettuce, also a Compositae as sunflower, when using the viral promoter CaMV35S. In consequence, our next step in sunflower transformation will be to look for better promoters than the CaMV35S used in our assays until now.

\section{ACKNOWLEDGMENTS}

We wish to thank Mr. A. Montenegro and Ms. V. Peralta for their collaboration at the greenhouse.

\section{REFERENCES}

GULYA, T.J.; SHIEL, P.J.; FREEMAN, T.; JORDAN, R.L.; ISAKEIT, T. and BERGER, P.H. Host range and characterization of Sunflower mosaic virus. Phytopathology, 2002, vol. 92, p. 694-702.

HEWEZI, T.; PERRAULT, A.; ALIBERT, G. and KALLERHOFF, J. Dehydrating immature embryo split apices and rehydrating with Agrobacterium tumefaciens: A new method for genetically transforming recalcitrant sunflower. Plant Molecular Biology Reporter, December 2002, vol. 20, no. 4, p. 335-345.

HOOD, E.; GELVIN, S.B.; MELCHERS, L.S. and HOEKEMA, A. New Agrobacterium helper plasmids for gene transfer to plants. Transgenic Research, July 1993, vol. 2 , no. 4, p. 208-218.

MCCABE, M.S.; SCHEPERS, F.; VAN DER AREND, A.; MOHAPATRA, U.; DE LAAT, A.M.M.; POWER, J.B. and DAVEY, M.R. Increased stable inheritance of herbicide resistance in transgenic lettuce carrying a petE promoter-bar gene compared with a CaMV 35S-bar gene. 
Theoretical and Applied Genetics, 1999, vol. 99, no. 3-4, p. 587-592.

MELCHERS, L.S. and STUIVER, M.H. Novel genes for disease-resistance breeding. Current Opinion in Plant Biology, 2000, vol. 3, no. 2, p. 147-152.

PUNJA, Z.K. Genetic engineering of plants to enhance resistance to fungal pathogens-a review of progress and future prospects. Canadian Journal of Plant Pathology, 2001, vol. 23, no. 3, p. 216-235.

RADONIC, L.M.; ZIMMERMANN, J.M.; ZAVALLO, D.; LÓPEZ, N. and LÓPEZ BILBAO, M. Rooting in $\mathrm{Km}$ selective media as efficient in vitro selection method for sunflower genetic transformation. Electronic Journal of Biotechnology, April 2006, vol. 9, no. 3, p. 315-319.

SAGHAI-MAROOF, M.A.; SOLIMAN, K.M.; JORGENSEN, R.A. and ALLARD, R.W. Ribosomal DNA Spacer-Length Polymorphisms in Barley: Mendelian Inheritance, Chromosomal Location, and Population Dynamics. Proceedings of the National Academy of Sciences of the United States of America, December 1984, vol. 81 , no. 24 , p. 8014-8018.

VELLICCE, G.R.; DIAZ RICCI, J.C.; HERNÁNDEZ, L. and CASTAGNARO, A. Enhanced resistance to Botrytis cinerea mediated by the transgenic expression of the chitinase gene ch5B in strawberry. Transgenic Research, February 2006, vol. 15, no. 1, p. 57-68.

WEBER, S.; FRIEDT, W.; LANDES, N.; MOLINIER, J.; HIMBER, C.; ROUSSELIN, P.; HAHNE, G. and HORN, R. Improved Agrobacterium -mediated transformation of sunflower (Helianthus annuus L.): assessment of macerating enzymes and sonication. Plant Cell Reports, January 2003, vol. 21, no. 5, p. 475-482. 